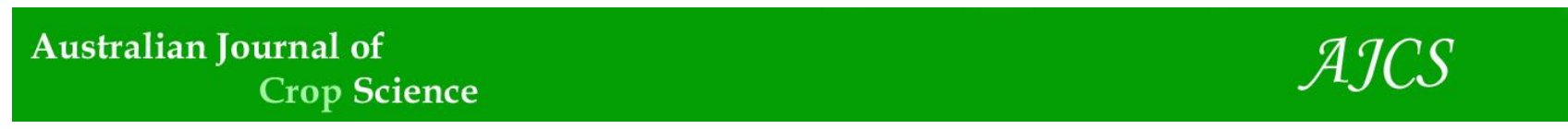

AJCS 12(10):1676-1684 (2018)

ISSN:1835-2707

doi: 10.21475/ajcs.18.12.10.pne1430

\title{
Pre-germination treatments in four prickly pear cactus (Opuntia sp.) species from Northeastern Mexico
}

\author{
Areli Gonzalez-Cortés ${ }^{1}$, M. Humberto Reyes-Valdés ${ }^{1}$, Valentín Robledo-Torres ${ }^{2}$, José A. Villarreal- \\ Quintanilla ${ }^{3}$ and Francisca Ramírez-Godina ${ }^{1^{*}}$
}

${ }^{1}$ Programa de Doctorado en Recursos Fitogenéticos para Zonas Áridas (Ph.D. Program in Plant Genetic Resources for Arid Lands)

${ }^{2}$ Departamento de Horticultura (Horticultural Department)

${ }^{3}$ Departamento de Botánica (Botanical Department), Universidad Autónoma Agraria Antonio Narro. Calzada

Antonio Narro 1923, Buenavista, C.P. 25315 Saltillo, Coahuila, México

*Corresponding author: godramf@gmail.com

\begin{abstract}
Prickly pear cactus (Opuntia sp.) is a major plant genus in arid and semiarid lands, due to its abundance, valuable contribution to human diet and use in animal feed. It also has a role in desertification control. Physiological assays on Opuntia seedlings and comparison among species are limited due to the lack of germination and seedling development methodologies. The purpose of this research was to assess the seed germination and the speed of emergence in four species: 0 . engelmannii, $O$. microdasys, $O$. rastrera and $O$. megacantha, distributed around Coahuila's Southeastern region in Mexico. We used a completely random experimental design with 23 pre-germination treatments and 4 replications. Seeds of 16 treatments were sown in Peat Moss and Perlite; while the seeds of seven treatments were placed at in vitro culture. We monitored the emergence of seedlings during 23 days. We observed highly significant differences among species and treatments. $O$. engelmannii and $O$. microdasys seeds had germination percentages of $82.5 \%$ and $67.5 \%$, respectively, by sanding then soaking in $3 \%$ hydrogen peroxide $\left(\mathrm{H}_{2} \mathrm{O}_{2}\right)$ for 24 hours; while $O$. rastrera reached a cumulative germination percentage of $72.5 \%$ with sanded seeds. $O$. megacantha had the highest germination percentage (100\%) after soaking the seeds in $3 \% \mathrm{H}_{2} \mathrm{O}_{2}$ for 24 hours. Scarifying treatments for six days of incubation resulted in faster seed emergence in the four assessed species. The results show that the most effective methodologies for seed germination and seedling development in Opuntias are manual and chemical scarification, since scuffing the seed coat can interrupt dormancy.
\end{abstract}

Keywords: Cactaceae, Dormancy, Germination, Prickly pear cactus, Reproduction, Seed, Scarification.

Abbreviations: $\mathrm{GA}_{3}$ Gibberellic acid; GP_Germination percentage; $\mathrm{H}_{2} \mathrm{O}_{2}$ _Hydrogen peroxide; IAA_Indole-3-Acetic Acid; MS_culture medium Murashige \& Skoog; ppm_Parts per million; SA_Salicylic acid; VE_speed of emergence.

Introduction

The Opuntia genus belongs to the Opuntioideae subfamily (Cactaceae). It is the most diverse genus with broad geographical distribution encompassing from Canada and North America to Chile and Argentina (Anderson, 2001; Wallace and Dickie, 2002; Britton and Rose, 1963). Mexico is considered the richest source of this genus, where there is more than 93 wild species (Mandujano et al., 2002; Guzmán et al., 2003; Guzmán et al., 2007; Scheinvar, 2009). Opuntia species are commonly called prickly pears cactus ("nopales"); succulent plants with the capacity of adaptation to high temperatures and lack of water. These plants are; therefore, some of the most important plant genetic resources in arid and semiarid regions (Bravo, 1978; Bravo and Scheinvar, 1995; Pinkava, 2002; Muñoz et al., 2008). In Australia, Italy and South Africa there are naturalized Opuntia species, while in Africa, America, Asia and Europe there are plantations for the production of fruit, animal feed and dyestuff (Reyes Agüero et al., 2006; Sáenz et al., 2006). Since 9000 years ago, human being has had a close relationship with Opuntia species that have become important biological, cultural, economic and social resources. At present, prickly pear cactus has more than 20 different uses, including food, medicine, feed, ornamental, fuel, and desertification control (Mandujano et al., 2001; Reyes-Agüero et al., 2005, Sáenz et al., 2006). Those species are part of the natural landscape and the agricultural systems in different regions of the world; and therefore, researchers are studying them to find new techniques that can help ensuring the genetic stock conservation, while promoting sustainable uses of this highly valuable resource for arid and semiarid regions. Nevertheless, the type of propagation sets limits to breeding research work, because it is asexual and it is the main scattering mechanism in wild populations (Mandujano et al., 2005); leaving aside sexual 
reproduction than maintains genetic variability, protects plants' scattering potential and it is essential for breeding (Reyes-Agüero et al., 2006). The problem with sexual reproduction is that prickly pear cactus seeds have very hard seed coats, leading to dormancy and long germination periods. There is very little knowledge on the optimal germination conditions (Palleiro et al., 2006). Dormancy is a type of survival mechanism resulting from physical, physiological, chemical or mechanical causes (Pérez et al., 2009; Heather et al., 2010; ISTA, 2012). One of the main dormancy causes is the presence of hard water and gasproof seed coats impairing or delaying germination. This happens with Opuntia seeds that have physiological dormancy and require a ripening period to germinate (Monroy et al., 2017; Orozco et al., 2007). Opuntia seeds are wrapped in a lignin-rich funicular layer that makes germination more difficult (Sánchez et al., 2015; Bregman and Bouman, 1983). Mandujano et al. (1996) have noted that out of 600 prickly pear cactus seeds, just one produces a plant, while Delgado et al. (2013) observed that by establishing an experiment without any treatment, the germination percentage is almost zero. Therefore it is important to assess different treatments that can shorten the emergence time while increasing the emergence rate (Schütz et al., 2002; Thompson et al., 2003). The few germination assays carried out on different species of Opuntia and the methods applied use mechanical and chemical scarification with acid or growth regulators that help breaking the seed coat and facilitate seedlings' emergence (Delgado et al., 2013). It is necessary to standardize a methodology for every species. Therefore, this assay was aimed to assess the seed germination rate of four Opuntia species $(O$. engelmannii, $O$. megacantha, $O$. microdasys and $O$. rastrera) distributed in Northeastern Mexico to contribute the prickly pear cactus breeding programs and the development of new varieties demanded by growers; besides creating in situ and ex situ conservation strategies.

\section{Results}

\section{Germination percentage}

When doing a graphic comparison using a box diagram of the 23 assessed pre-germination treatments, we noticed differences in the total number of germinated seeds, finding from 0 to $100 \%$ germination rates, getting the best response from $T_{5}$ (Fig. 1). The opposite happened when we compared the four assessed species, since we observed no evident differences. However, in $O$. megacantha and $O$. rastrera we found a higher GP, between 87 and 100\%; while in $O$. engelmannii the GP was $82 \%$; and $O$. microdasys was the species with the lowest GP of $67 \%$ (Table 1, Fig. 2)

Multiple comparisons of means proved that sanding and soaking seeds in $3 \% \mathrm{H}_{2} \mathrm{O}_{2}$ for 24 hours $\left(\mathrm{T}_{5}\right)$, results in an average germination percentage of $70 \%$. Application of $\mathrm{H}_{2} \mathrm{O}_{2}$ at $3 \%\left(T_{2}\right)$ or at $5 \%$ with mechanical scarification $\left(T_{6}\right)$ resulted in average germination percentage of $60 \%$. The in vitro soaking treatments with $\mathrm{GA}_{3}$ at different concentrations resulted in average germination percentages lower than $30 \%$ (Fig. 3).

The multiple pairwise comparisons (Fig. 3), shows that treatments 5, 2, 6, 3 and 4 form a single statistical group with superior performance. These five treatments have had the use of scarification in common, either chemical with hydrogen peroxide, or physical by sanding.

Species-treatment interaction: The interaction chart of the four species with 23 treatments shows the following results: The highest cumulative GP in 0 . rastrera was $87.5 \%$ using $\mathrm{T}_{6}$ : mechanical scarification (sanded seeds) plus chemical scarification (soaking in $\mathrm{H}_{2} \mathrm{O}_{2}$ at $5 \%$ for 24 hours), contrary to what happened with the check test $\left(T_{1}\right)$, in which the GP was lower than $20 \%$. Treatments with $\mathrm{GA}_{3}$ at different concentrations and water soaking at different temperatures resulted in very low GPs, between 20 and $0 \%$. On the other hand, we obtained a GP of $40 \%$ (Fig. 4) by conducting in vitro germination with only an MS culture medium without $\mathrm{GA}_{3}$. In $O$. microdasys, the most efficient treatment was $T_{5}$ : mechanical scarification (sanded seeds) plus chemical scarification (soaking in $\mathrm{H}_{2} \mathrm{O}_{2}$ for 24 hours), leading to a GP of $67.5 \%$. Chemical scarification by itself $\mathrm{T}_{6}$, also exhibited significant results, but the percentages were lower than $60 \%$. Immersion in water at the boiling point for different times $\left(T_{7}, T_{8}, T_{9}, T_{10}\right) ; G A_{3}$ at different concentrations $\left(T_{12}, T_{13}\right.$, $\left.T_{14}, T_{15}, T_{16}\right)$ and no treatment at all $\left(T_{1}\right)$ produced a GP lower than $25 \%$. However, we can obtain $60 \%$ in vitro germination by applying $\mathrm{MS}$ at $50 \%$ plus $\mathrm{GA}_{3}$, at a concentration of 0.5 $\mathrm{mg} / \mathrm{L}\left(\mathrm{T}_{20}\right)$. The same trend was observed in $O$. engelmannii species, where $T_{5}$ resulted in a GP greater than $80 \%$, opposite of what happened with the check test $\left(T_{1}\right)$ and treatments $T_{10}, T_{12}, T_{13}, T_{15}, T_{16}, T_{17}$ and $T_{20}$, where no positive responses were found, since GP was $0 \%$. These observations indicate that water soaking at ambient temperature and $\mathrm{GA}_{3}$ applied at 50, 100 and $200 \mathrm{ppm}$ do not promote germination in this species; however, we can obtain a GP of $40 \%$ in vitro, with $\mathrm{MS}$ at $50 \%$ and $\mathrm{GA}_{3}$ at a concentration of $0.5 \mathrm{mg} / \mathrm{L}\left(\mathrm{T}_{20}\right)$. By treating $O$. megacantha seeds with mechanical scarification $\left(T_{2}\right)$, we can obtain a GP of $100 \%$; but just as it happens with $O$. mycrodasis and $O$. engelmannii, $\mathrm{T}_{5}$ also produces good results; since mechanical scarification combined with chemical scarification resulted in a GP of $80 \%$; in contrast with treatments $T_{12}$ to $T_{23}$, where seeds did not germinate (Fig. 4).

\section{Emergence speed}

In average, the seedlings started emerging six days after planting and they finally emerged after twenty days, with 0.15 seeds germinating every day. In the test check $\left(T_{1}\right)$, emergence started on the fifth day and finished on day 17, with less than $20 \%$ germination. This result is contrasting versus the treatments resulting in positive GPs, from the four tested species $\left(T_{2}, T_{5}\right.$ and $\left.T_{6}\right)$, where emergence started on day 4 and day 5 and the rate kept growing, until obtaining 60 and $70 \%$ seedlings on day 18 and day 20 (Fig. 5).

\section{Discussion}

Pre-germination treatments using mechanical scarification with sandpaper and chemical scarification with $\mathrm{H}_{2} \mathrm{O}_{2}$, promoted germination in 0 . megacantha, $O$. microdasys, $O$. rastrera and $O$. engelmannii, with GPs ranging from 67 to $100 \%$. These species from arid regions have difficulties to germinate because their seeds suffer from severe water restrictions (Harper, 1997; Sánchez et al., 2010) and extreme 
temperature conditions. Due to their origin and the heatsensitive regime to which they are exposed, these species have hydrophobic compounds. Therefore, the effects of $\mathrm{H}_{2} \mathrm{O}_{2}$ and sanding are the result of an increase in the permeability of the seed coat after scuffing the lignin-rich funicular layer, allowing the entrance of water required for the imbibition and gas exchange processes that are indispensable in germination (Chikumba et al., 2006). On the other hand, sanding helped scuffing the seed coat. The seed coat requires 0.2 to 4.6 kN (López et al., 2015); or 1.59 - 1.68 kN (Aguilar et al., 2003; Reyes-Agüero et al., 2005) to crack and allow the embryo to emerge easily (Orozco et al., 2007); while $\mathrm{H}_{2} \mathrm{O}_{2}$ induces germination by producing hormonal changes (Barba et al., 2011). Application of $\mathrm{GA}_{3}$ in concentrations of 50, 100 and $200 \mathrm{ppm}$ resulted in zero GP in all four species. These results coincide with the results obtained by Olvera (2001) and Mandujano et al. (2007), who applied $\mathrm{GA}_{3}$ at $200 \mathrm{ppm}$ in two Opuntia species, without positive results. Therefore, we can assume that the use of gibberellins in concentrations ranging from 50 to $200 \mathrm{ppm}$ do not interrupt dormancy and do not induce seed germination in Opuntia. Nevertheless, these plant hormones may work at lower concentrations and shorter times, since Sánchez (1997) applied 40 ppm, for 30 minutes to Opuntia joconostle seeds with positive results, while Olvera (2001) mentioned that seed germination in $O$. tomentosa did not increase by adding $\mathrm{GA}_{3}$ at $1000 \mathrm{ppm}$. These results lead us to think that applying gibberellins on Opuntia seeds at high concentrations does not work. Although we know that $\mathrm{GA}_{3}$ promotes germination by inducing a-amilase synthesis, the enzyme that helps breaking down starch reserves during germination. According to the reports, the effects of gibberellins on cacti are rather rare and widely diverse. Likewise, soaking treatments with hot water did not promote germination on the tested species. This is in contrary to the results obtained by Mondragón and Bordelon (2002), who soaked $O$. ficus indica seeds in hot water, from $80^{\circ} \mathrm{C}$ to ambient temperature. The seeds were soaked for 24 hours, reaching an average germination percentage of $54 \%$. However, it seems that a higher temperature $\left(100^{\circ} \mathrm{C}\right)$ treatment applied to the seeds damaged the embryos, impairing germination and emergence. Those results coincide with Sánchez et al. (2016), who observed that seeds of $O$. streptacantha dipped in hot water $\left(98^{\circ} \mathrm{C}\right)$ for 20 seconds did not germinate. GPs response from the in vitro pre-germination treatment was also lower than the response obtained by applying mechanical and chemical scarification; since the GP arising from those treatments ranged from 0 to $60 \%$, indicating that the addition of macro and micronutrients, as well as salicylic acid $(\mathrm{SA})$ and $\mathrm{GA}_{3}$, did not have any effect on germination. This might be because seeds require chemical and mechanical scarification to promote germination. Furthermore, it is possible to establish sanded seeds to promote seedling emergence.

According to the results herein, we recommend sanding $O$. engelmannii and $O$. microdasys seeds followed by soaking in $\mathrm{H}_{2} \mathrm{O}_{2}$ at low concentrations (3\%), because higher peroxide levels lead to lower germination rates. On the contrary, $O$. rastrera required a $5 \%$ concentration of $\mathrm{H}_{2} \mathrm{O}_{2}$ to reach GPs greater than $80 \%$; while $\mathrm{O}$. megacantha only requires $3 \%$ $\mathrm{H}_{2} \mathrm{O}_{2}$ for $24 \mathrm{hrs}$ to obtain high GPs, up to $100 \%$. It is important to apply pre-germination scarification treatments to Opuntia species to obtain high GPs due to their seed coat hardness. Otherwise, the germination rate will be zero, as occurred in control, yielding 0 to $15 \%$ GPs. These results agree with Delgado et al. (2013) reports, where the germination rate of untreated prickly pear cactus seeds was almost zero.

\section{Emergence speed}

The emergence speed increased in the best treatments, where germination started 5 and 6 days after planting in the 4 tested species. Therefore, the methods based on mechanical-chemical scarification help accelerating germination, considered slow and reduced in Opuntia species. We estimate that seeds from this genus take in average 13 days to start germinating. Mondragon and Bordelon (2002) obtained similar results when testing seeds from different Mexican prickly pear cactus clones, where germination starts between 7 and 10 days after planting, and need enough time to reach the maximum percentage at 32 to 86 days. The same occurred when assessing seeds of $O$. streptacantha, obtaining the highest percentage of emerged seedlings after 34 days (Sánchez et al., 2016). The opposite results were observed in this assay, where we obtained the highest GP at 20 days. Based on these results, we can say that mechanical and chemical scarification is the most effective treatment, reaching a higher germination percentage in a short time, unlike the other treatments, including the check test.

\section{Materials and Methods}

\section{Plant materials}

During the months of July-September 2016, the field trips were carried out to collect ripen fruits of four Opuntia species. One of those species is half-domesticated $(O$. megacantha,) and three of them are wild $(O$. engelmannii, $O$. microdasys and $O$. rastrera). We toured four municipalities located in Coahuila's southeastern region (Arteaga, General Cepeda, Ramos Arizpe and Saltillo). The collection regions were between $25^{\circ} 02.406^{\prime}$ a $25^{\circ} 50.657^{\prime}$ North latitude and $100^{\circ} 00.646^{\prime}$ a $101^{\circ} 57.720^{\prime}$ West longitude, in altitudes ranging from 930 to 2464 meters above sea level (Table 2, Fig. 6).

\section{Seed collection}

In order to obtain the seeds after collecting the fruits, we cleaned and peeled them off in the laboratory. We mixed the pulp in a blender with the blades covered by tape, to avoid breaking the seed coat. We filtered the blend using a regular strainer and we washed it several times to clean all the pulp stuck on the seeds until the last trace. We dried the seeds on felt paper for 72 hours at mean ambient temperature of $25^{\circ} \mathrm{C}$ to avoid mold growth during storage. We kept the seeds inside brown paper bags at $25^{\circ} \mathrm{C}$ until using them (Fig. 7). We sorted out the seeds visually, eliminating smaller, paler, abortive and malformed seeds; leaving only fully developed seeds, with no apparent damage. Before starting the experiment, we dipped the 
Table 1. Comparison of the germination percentage among Opuntia species, obtained from different test treatments, established in peat moss and perlite substrate, as well as in vitro culture medium.

\begin{tabular}{|c|c|c|c|c|c|c|c|c|}
\hline \multirow[t]{2}{*}{ Treat. } & \multicolumn{2}{|c|}{ O. engelmanii } & \multicolumn{2}{|c|}{ O. megacantha } & \multicolumn{2}{|c|}{ O. microdasys } & \multicolumn{2}{|c|}{ O. rastrera } \\
\hline & $\%$ & SE & $\%$ & SE & $\%$ & SE & $\%$ & SE \\
\hline \multicolumn{9}{|c|}{ Establishment: peat moss and perlite } \\
\hline $\mathrm{T}_{1}$ & 0.00 & 0.00 & 17.5 & 6.29 & 0.00 & 0.00 & 15.0 & 2.88 \\
\hline $\mathrm{T}_{2}$ & 35.0 & 2.88 & 100.0 & 0.00 & 55.0 & 2.88 & 55.0 & 2.88 \\
\hline $\mathrm{T}_{3}$ & 42.5 & 2.50 & 77.5 & 6.29 & 42.5 & 2.50 & 62.5 & 4.78 \\
\hline $\mathrm{T}_{4}$ & 57.5 & 2.50 & 40.0 & 7.07 & 27.5 & 2.50 & 72.5 & 2.50 \\
\hline $\mathrm{T}_{5}$ & 82.5 & 2.50 & 77.5 & 7.50 & 67.5 & 2.50 & 52.5 & 4.78 \\
\hline $\mathrm{T}_{6}$ & 47.5 & 2.50 & 55.0 & 6.45 & 50.0 & 4.08 & 87.5 & 4.78 \\
\hline $\mathrm{T}_{7}$ & 12.5 & 4.78 & 0.00 & 0.00 & 0.00 & 0.00 & 12.5 & 4.78 \\
\hline $\mathrm{T}_{8}$ & 12.5 & 2.50 & 20.0 & 4.08 & 0.00 & 0.00 & 0.00 & 0.00 \\
\hline $\mathrm{T}_{9}$ & 22.5 & 4.78 & 0.00 & 0.00 & 0.00 & 0.00 & 0.00 & 0.00 \\
\hline $\mathrm{T}_{10}$ & 0.00 & 0.00 & 57.5 & 8.53 & 20.0 & 4.08 & 17.5 & 6.29 \\
\hline $\mathrm{T}_{11}$ & 27.5 & 4.78 & 12.5 & 6.29 & 27.5 & 2.50 & 20.0 & 5.77 \\
\hline $\mathrm{T}_{12}$ & 0.00 & 0.00 & 0.00 & 0.00 & 0.00 & 0.00 & 0.00 & 0.00 \\
\hline $\mathrm{T}_{13}$ & 0.00 & 0.00 & 0.00 & 0.00 & 0.00 & 0.00 & 0.00 & 0.00 \\
\hline $\mathrm{T}_{14}$ & 12.5 & 4.78 & 0.00 & 0.00 & 15.0 & 2.88 & 15.0 & 2.88 \\
\hline $\mathrm{T}_{15}$ & 0.00 & 0.00 & 0.00 & 0.00 & 0.00 & 0.00 & 0.00 & 0.00 \\
\hline $\mathrm{T}_{16}$ & 0.00 & 0.00 & 0.00 & 0.00 & 0.00 & 0.00 & 0.00 & 0.00 \\
\hline \multicolumn{9}{|c|}{ Establishment: in vitro } \\
\hline $\mathrm{T}_{17}$ & 27.5 & 2.50 & 0.00 & 0.00 & 27.5 & 2.50 & 0.00 & 0.00 \\
\hline $\mathrm{T}_{18}$ & 0.00 & 0.00 & 0.00 & 0.00 & 0.00 & 0.00 & 10.0 & 4.08 \\
\hline $\mathrm{T}_{19}$ & 0.00 & 0.00 & 0.00 & 0.00 & 17.5 & 2.50 & 20.0 & 4.08 \\
\hline $\mathrm{T}_{20}$ & 42.5 & 4.78 & 0.00 & 0.00 & 60.0 & 4.08 & 0.00 & 0.00 \\
\hline $\mathrm{T}_{21}$ & 25.0 & 2.88 & 0.00 & 0.00 & 37.5 & 4.78 & 10.0 & 4.08 \\
\hline $\mathrm{T}_{22}$ & 0.00 & 0.00 & 0.00 & 0.00 & 0.00 & 0.00 & 22.5 & 4.78 \\
\hline $\mathrm{T}_{23}$ & 17.5 & 2.50 & 0.00 & 0.00 & 35.0 & 2.88 & 40.0 & 4.08 \\
\hline
\end{tabular}

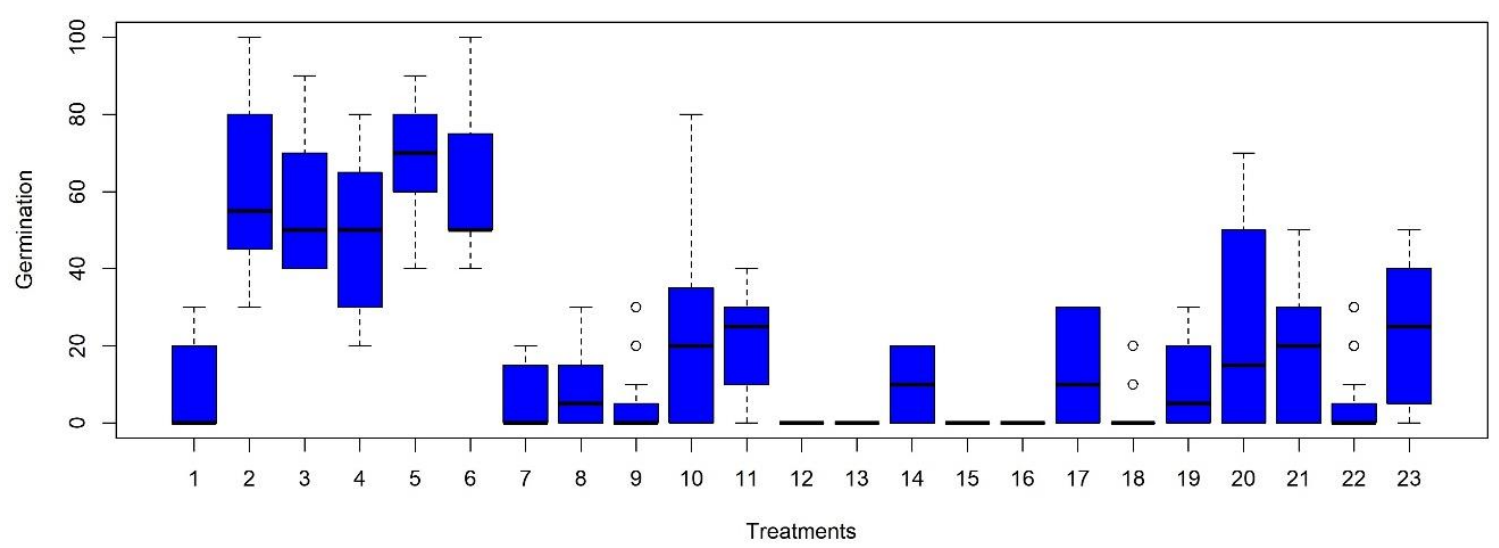

Fig 1. Comparison among the twenty-three treatments for the total number of germinated seeds.

Table 2. Collection sites of four tested Opuntia species, using different pre-germination treatments.

\begin{tabular}{|c|c|c|c|c|c|}
\hline Species & $\begin{array}{l}\text { Domestication } \\
\text { degree }\end{array}$ & Collection site & North latitude & West longitude & Altitude (m) \\
\hline O. engelmanii & Wild & Ramos Arizpe, Coahuila, Mex. & $25^{\circ} 34.420^{\prime}$ & $101^{\circ} 11.360^{\prime}$ & 1793 \\
\hline O. megacantha & $\begin{array}{l}\text { More or less } \\
\text { domesticated }\end{array}$ & Arteaga, Coahuila, Mex. & $25^{\circ} 27.780^{\prime}$ & $100^{\circ} 36.580^{\prime}$ & 2296 \\
\hline O. microdasys & Wild & Saltillo, Coahuila. Mex. & $25^{\circ} 02.931^{\prime}$ & $101^{\circ} 15.965^{\prime}$ & 1950 \\
\hline O. rastrera & Wild & General Cepeda, Coahuila, Mex. & $25^{\circ} 22.913^{\prime}$ & $101^{\circ} 11.624^{\prime}$ & 1839 \\
\hline
\end{tabular}




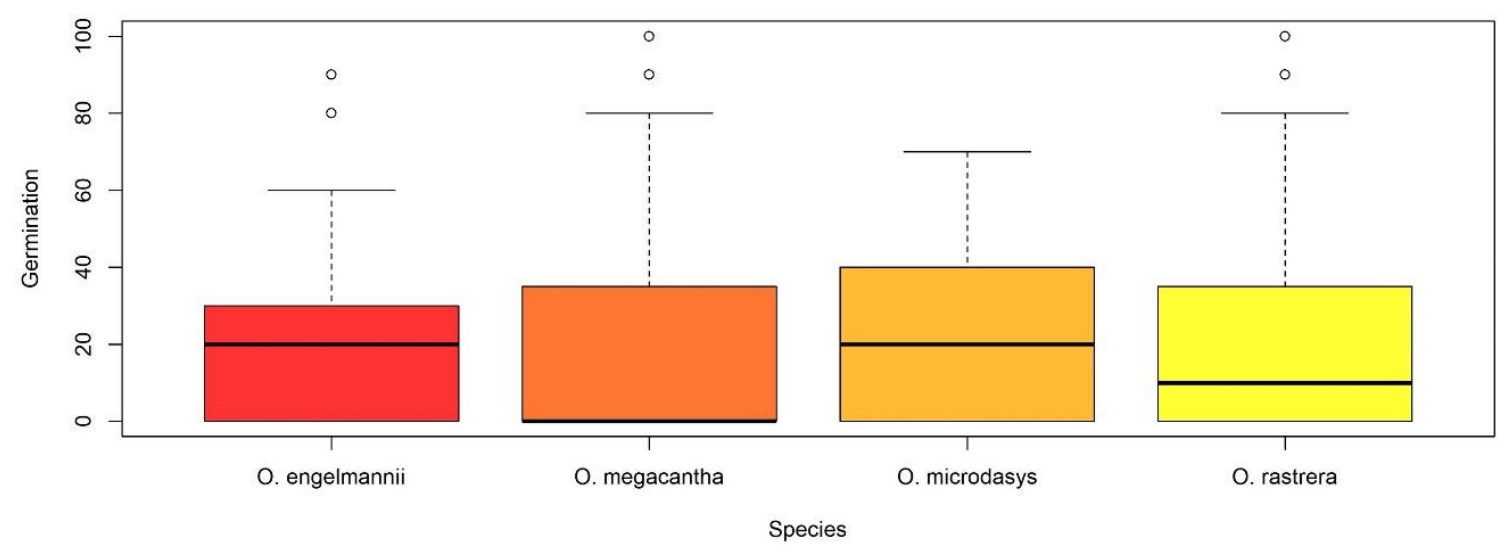

Fig 2. Comparison among species regarding the number of germinated seeds.

Table 3. Treatments used in assessing germination in four Opuntia species, established in peat moss and perlite substrates.

\begin{tabular}{ll}
\hline Treatment number & Treatment description \\
\hline $\mathrm{T}_{1}$ & Check test \\
$\mathrm{T}_{2}$ & Hydrogen peroxide $\left(\mathrm{H}_{2} \mathrm{O}_{2}\right)$ at $3 \%$ for 24 hours \\
$\mathrm{T}_{3}$ & Hydrogen peroxide $\left(\mathrm{H}_{2} \mathrm{O}_{2}\right)$ at $5 \%$ for 24 hours \\
$\mathrm{T}_{4}$ & Sanded seed (scarified) \\
$\mathrm{T}_{5}$ & Sanded seed + Hydrogen peroxide $\left(\mathrm{H}_{2} \mathrm{O}_{2}\right)$ at $3 \%$ for $24 \mathrm{hrs}$ \\
$\mathrm{T}_{6}$ & Sanded seed $+\mathrm{Hydrogen}$ peroxide $\left(\mathrm{H}_{2} \mathrm{O}_{2}\right)$ at $5 \%$ for $24 \mathrm{hrs}$ \\
$\mathrm{T}_{7}$ & Water soaking at $100^{\circ} \mathrm{C}$ for 10 seconds \\
$\mathrm{T}_{8}$ & Water soaking at $100^{\circ} \mathrm{C}$ for 5 seconds \\
$\mathrm{T}_{9}$ & Water soaking at $100^{\circ} \mathrm{C}$ until reaching ambient temperature \\
$\mathrm{T}_{10}$ & Water soaking for $24 \mathrm{hours}$ \\
$\mathrm{T}_{11}$ & Water soaking for $24 \mathrm{hrs}+50 \mathrm{ppm}$ of gibberellic acid $\left(\mathrm{GA}_{3}\right)$ \\
$\mathrm{T}_{12}$ & Water soaking for $24 \mathrm{hrs}+100 \mathrm{ppm}$ of gibberellic acid $\left(\mathrm{GA}_{3}\right)$ \\
$\mathrm{T}_{13}$ & Water soaking for $24 \mathrm{hrs}+200 \mathrm{ppm}$ of gibberellic acid $\left(\mathrm{GA}_{3}\right)$ \\
$\mathrm{T}_{14}$ & Water soaking for $48 \mathrm{hrs}+50 \mathrm{ppm}$ of gibberellic acid $\left(\mathrm{GA}_{3}\right)$ \\
$\mathrm{T}_{15}$ & Water soaking for $48 \mathrm{hrs}+100 \mathrm{ppm}$ of gibberellic acid $\left(\mathrm{GA}_{3}\right)$ \\
$\mathrm{T}_{16}$ & Water soaking for $48 \mathrm{hrs}+200 \mathrm{ppm}$ of gibberellic acid $\left(\mathrm{GA}_{3}\right)$ \\
\hline
\end{tabular}

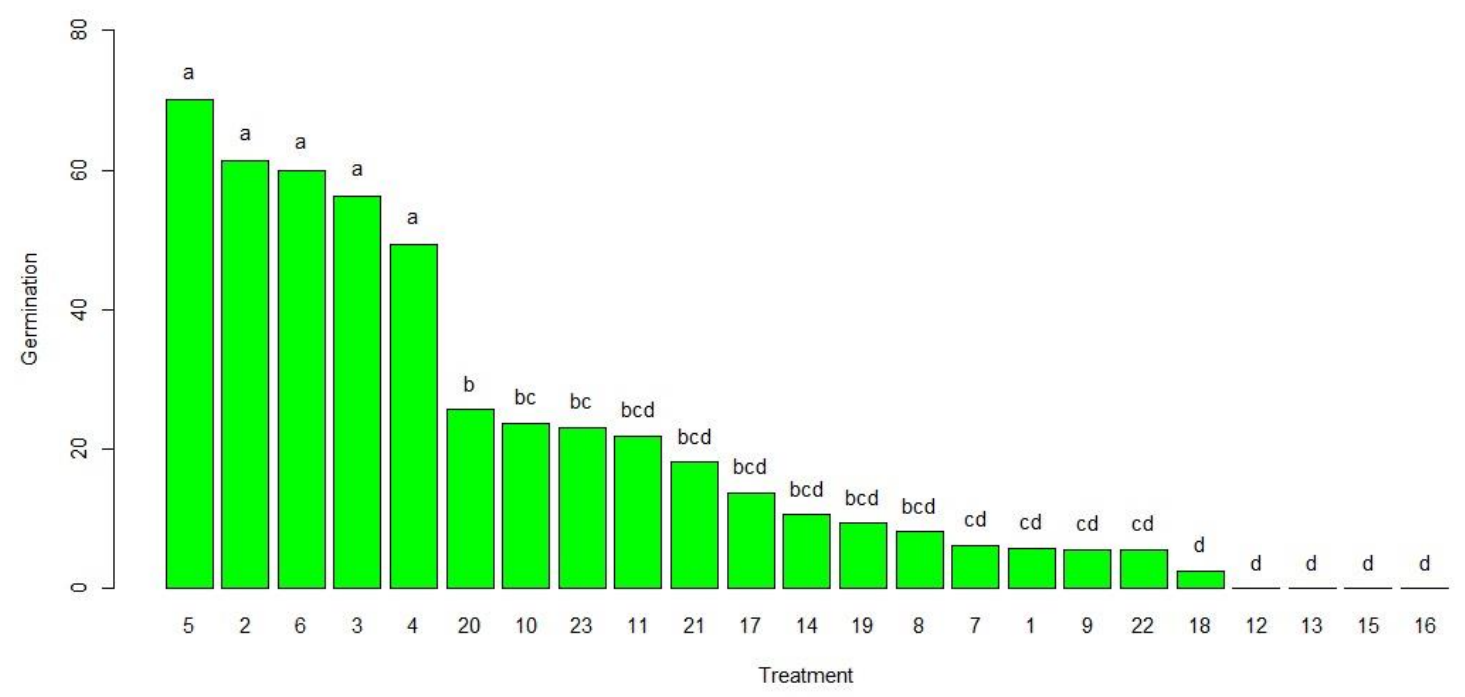

Fig 3. Response of 23 treatments for germination percentage, along with the grouping from multiple comparison of means. Footnote. Treatments with equal letters are not statistically different. 
Table 4. Treatments used in assessing germination in four Opuntia species established in vitro. (Continuation of Table 3)

\begin{tabular}{ll}
\hline Treatment number & Treatment description \\
\hline $\mathrm{T}_{17}$ & Agar + Sucrose \\
$\mathrm{T}_{18}$ & MS (Murashigue \& Skoot) at $50 \%+$ salicylic acid $(\mathrm{SA}) 0.5 \mathrm{mg} / \mathrm{L}$ \\
$\mathrm{T}_{19}$ & $\mathrm{MS}$ (Murashigue \& Skoot) at $50 \%+$ salicylic acid $(\mathrm{SA}) 1.0 \mathrm{mg} / \mathrm{L}$ \\
$\mathrm{T}_{20}$ & MS (Murashigue \& Skoot) at $50 \%+$ salicylic acid $\left(\mathrm{GA}_{3}\right) 0.5 \mathrm{mg} / \mathrm{L}$ \\
$\mathrm{T}_{21}$ & $\mathrm{MS}$ (Murashigue \& Skoot) at $50 \%+$ gibberellic acid $\left(\mathrm{GA}_{3}\right) 1.0 \mathrm{mg} / \mathrm{L}$ \\
$\mathrm{T}_{22}$ & MS (Murashigue \& Skoot) at $50 \%+$ gibberellic acid $\left(\mathrm{GA}_{3}\right) 1.5 \mathrm{mg} / \mathrm{L}$ \\
$\mathrm{T}_{23}$ & MS (Murashigue \& Skoot) at $50 \%$ \\
\hline
\end{tabular}

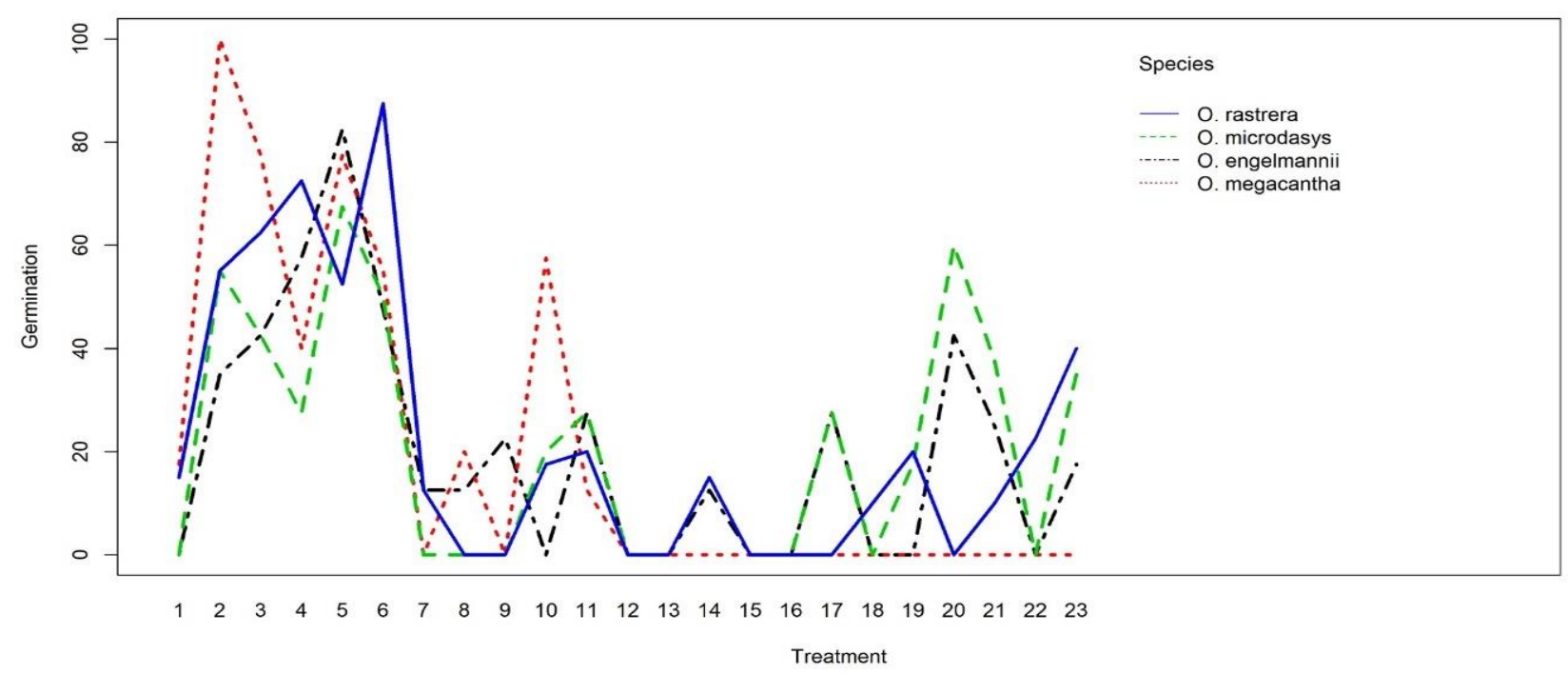

Fig 4. Graphical representation of the interaction among 23 treatments, representing differential responses in terms of germination percentage, across four Opuntia species.

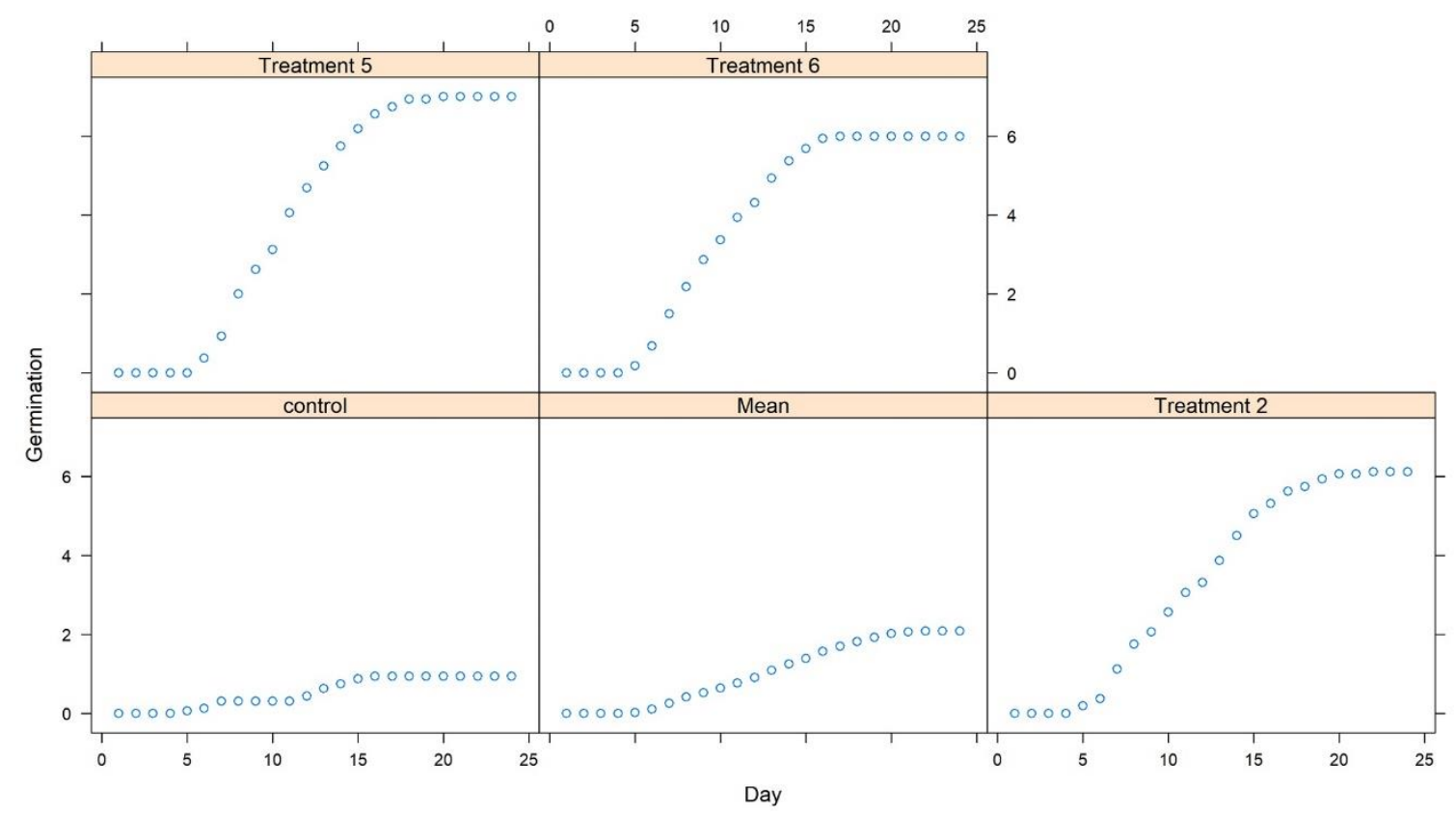

Fig 5. Emergence speed of the check test and the best treatments compared to the average. 

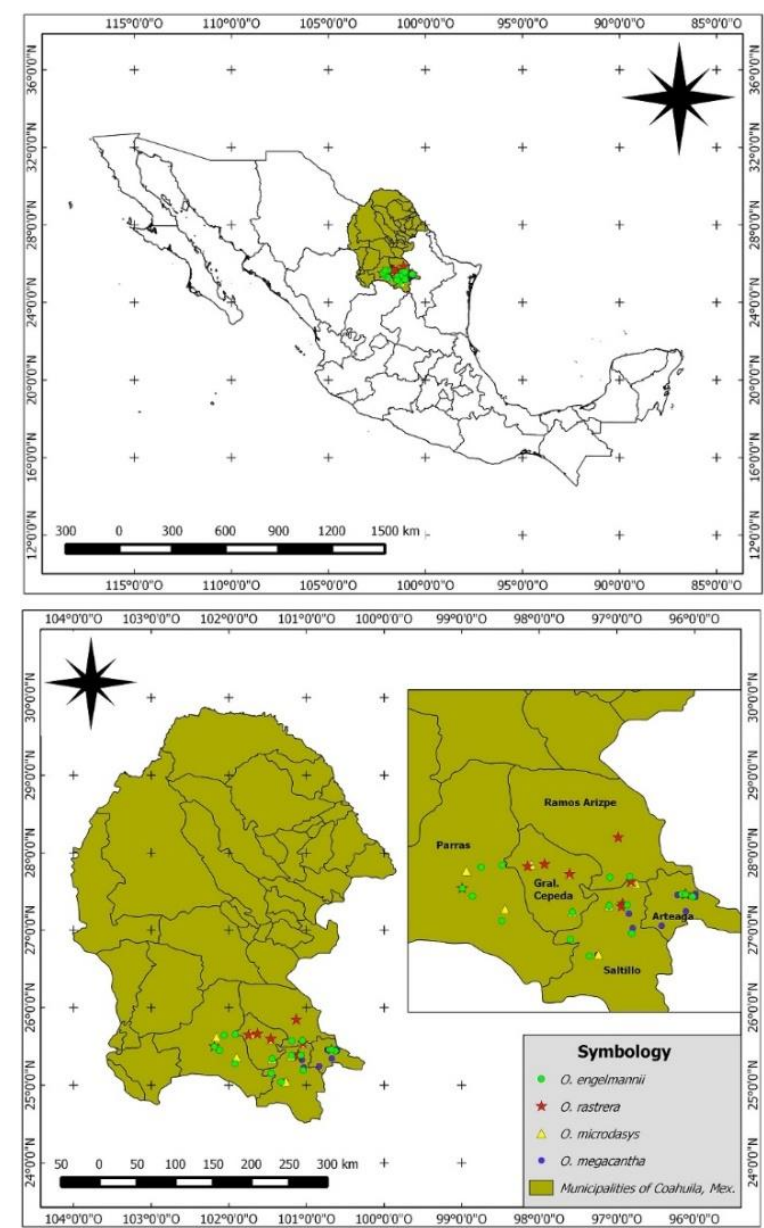

Fig 6. Collection route of Opuntia species in some municipalities of Coahuila's southeastern region, in Mexico.

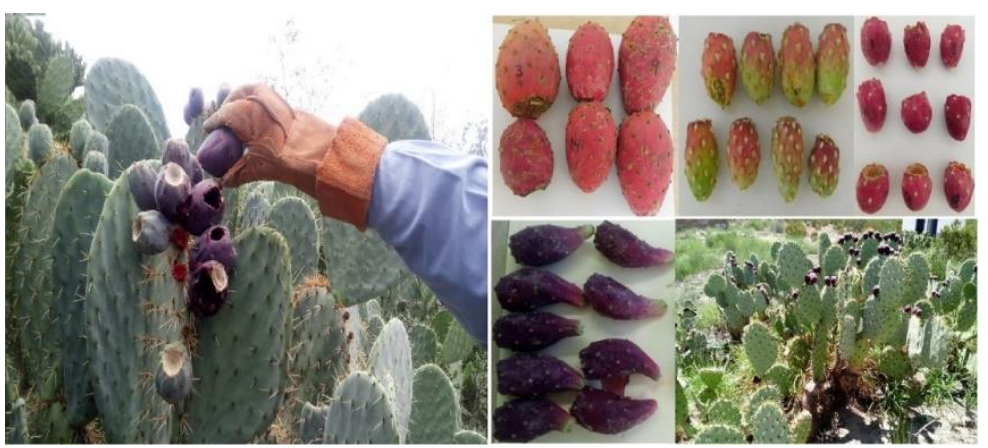

Fig 7. Fruit collection of different Opuntia species in some municipalities of Coahuila's southeastern region.

seeds in a glass with water to ensure that there were no hollow seeds (López et al., 2015).

\section{Germination trials}

For pre-germination, the seeds were handled with 23 treatments, including the control, which was established in perlite and peat moss substrate without pre-treatment. Two of those treatments included chemical scarification through hydrogen peroxide, one with physical scarification through sanding, and two with a combination of the two types. For 16 treatments the substrate was peat moss and perlite in a 1:1 ratio, whereas seven were established at an in vitro culture medium (Table 3 and 4), under dark and controlled temperature conditions. The dark condition was used because preliminary trials showed that seeds exposed to light take longer to germinate.

The experimental layout was a completely randomized factorial design with two factors: treatments and species, with four replications for combination and ten seeds per replication. The number of combinations was 92 , with a total of 368 entries.

Mechanical scarification: This process was carried out by hand scuffing of seed coat with fine grain sandpaper, trying to avoid damaging the internal tissue. 
Chemical scarification: We submerged tested seeds in a hydrogen peroxide dissolution $\left(\mathrm{H}_{2} \mathrm{O}_{2}\right)$ at a concentration of 3 and $5 \%$ for 24 hours, before rinsing them with distilled water to eliminate the excess of $\mathrm{H}_{2} \mathrm{O}_{2}$.

Hydration (water soaking): We placed the seeds inside a flask with $300 \mathrm{~mL}$ of water at the boiling point $\left(100^{\circ} \mathrm{C}\right)$ for 10 and 5 seconds, until reaching ambient temperature $\left(25^{\circ} \mathrm{C}\right)$. The seeds were also soaked in water at ambient temperature for 24 hours.

\section{Seed establishment in a substrate}

In treatments one to sixteen, we planted the seeds in peat moss + perlite substrate in a 1:1 ratio (Table 2 ), inside flat polypropylene germination trays. We planted the seeds at a depth twice the seeds' diameter. We saturated the seeds with water before covering them with plastic to keep them wet. We placed the trays inside a Lumistell IEC-41 germination stove under dark and temperature controlled conditions $\left(25 \pm 1^{\circ} \mathrm{C}\right)$.

\section{Seed establishment in vitro}

From treatment sixteen to treatment twenty-three we used an in vitro substrate (Table 3 ) and we disinfected the seeds before planting, following Villavicencio et al. (2009) protocol. We placed the seeds inside $70 \mathrm{~mL}$ Gerber ${ }^{\circledR}$ flasks, with $25 \mathrm{~mL}$ of MS culture medium (Murashige \& Skoog, 1962). We assessed them every day during 24 days and we considered them germinated as soon as they emerged from the substrate (Kester et al., 2001).

\section{Statistical analysis}

We assessed the following variables: germination percentage (GP) and speed of emergence (VE). To assess the treatment effects on germination response, we first performed plot-based exploratory analyses, with the use of bar, box and interaction plots. Since the number of germinated seeds is a counting variable, which may be unsuited for the classic analysis of variance, we applied linear generalized models for proportion data with categorical explanatory factors, as recommended by Crawley (2007). First, a generalized model with a binomial distribution was fitted, including an over-dispersion test. Since the over-dispersion index was above 1.5, the final generalized model was based on the quasibinomial distribution. The multiple comparisons were performed with the Tukey test. All the analyses were performed with the language and environment for statistical computing R ( $R$ Core Team, 2017), and its package multcomp.

\section{Conclusion}

With these results, we can confirm that Opuntia seeds of the four tested species coming from arid environments show endogenous dormancy with hard seed coats, as part of their adaptation, diversification and survival mechanisms. Such dormancy can be broken with scarification, producing up to $100 \%$ germination. There have been very few research studies focusing on Opuntia's seed germination rates and they have resulted in GPs lower than the GPs reported here.
Therefore, these results are promissing, especially for breeding purposes; vis-à-vis the fact that the reproduction system of species determines their genetic structure. These results can also promote the creation of germplasm banks that can preserve the genetic stock of natural populations. These efforts would ensure genetic heterogeneity leading to greater variability and stronger adaptation to different environments, as well as to seed propagation of wild species, for management purposes.

\section{Acknowledgements}

We thank to the National Council for Science and Technology (CONACYT) for a graduate student's scholarship and To the Universidad Autónoma Agraria Antonio Narro (UAAAN).

\section{References}

Aguilar EA, Reyes AJA, Aguirre RJR (2003) Caracterización de la semilla de 403 variantes de nopal (Opuntia spp.). Documento presentado en el IX congreso nacional y VII internacional sobre conocimiento y aprovechamiento del nopal, Universidad Autónoma de Zacatecas, México, 2-6 de septiembre de 2003.

Anderson EF (2001) The cactus family. In: Timber Press (ed). 1 edn. Portland, Oregon, USA. 484-525.

Barba EG, Diaz VP, Job D, Belghazi M, Job C, Hernándes JA (2011) Understanding the role of $\mathrm{H}_{2} \mathrm{O}_{2}$ during pea seed germination: a combined proteomic and hormone profiling approach. Plant Cell Environ. 34: 1907-1919.

Bravo HH (1978) Las cactáceas de México. In: Universidad Nacional Autónoma de México- Rodolfo Navarro Malváez (ed). Vol. I, 2a ed. México.743p.

Bravo HH, Scheinvar L (1995) El interesante mundo de las cactáceas. In: Universidad Nacional Autónoma de MéxicoFondo de Cultura Económica (ed). 1 edn. México. 233p.

Bregman R, Bouman F (1983) Seed germination in cactaceae. Bot J Linn Soc. 86(4): 357-374.

Britton NL, Rose JL (1963) The Cactaceae, description and illustrations of the plants of the cactus family. In: Dover Publications, Inc (ed). Vol. II. New York. 241p.

Chikumba N, Mapiye C, Poshiwa X (2006) Breaking seed coat dormancy in Macrotylomadaltonii. Rangeland J. 28(2): 179-182.

Crawley MJ (2007) The R book. In: John Wiley \& Sons, Ltd (ed). Chichester. 942p.

Delgado SP, Jiménez BJF, Guerrero GML, Flores J (2013) Effect of fungi and light on seed germination of three Opuntia species from semiarid lands of central México. J Plant Res. 126: 643-649.

Guzmán U, Arias S, Dávila P (2003) Catálogo de cactáceas mexicanas. In: Universidad Nacional Autónoma de México, CONABIO (ed). México D.F. 315p.

Guzmán U, Arias S, Dávila P (2007) Catálogo de autoridades taxonómicas de las cactáceas (Cactaceae: Magnoliopsida) de México. In: Facultad de Estudios Superiores Iztacala, UNAM. Base de datos SNIB-CONABIO (ed). México. 90p.

Harper JL (1997) The Population Biology of Plants. In: Academic Press (ed). New York USA. 892p. 
Heather AE, Pérez HE, Wilson SB (2010) Non-deep physiological dormancy in seeds of two Polygonella species with horticultural potential. Hortscience. 45 (12): 1854-1858.

ISTA- International Seed Testing Association (2012) International rules for seed testing. Rules, Bassersdorf, $\mathrm{CH}-$ Switzerland.

Kester DE, Fred T, Davies J, Hartmann HT, Geneve RL (2001) Plant propagation: principles and practices. Prentice Hall PTR. 880p.

López PC, Peña VCB, Reyes AJA, Aguirre RJR, Ramírez THM, Soto HRM, Jiménez BJF (2015) Inter- and intra-specific variation in fruit biomass, number of seeds, and physical characteristics of seeds in Opuntia spp., Cactaceae. Genet Resour Crop Ev. 62: 1205-1223.

Mandujano MC, Golubov J, Rojas AM (2007) Efecto del ácido giberélico en la germinación de tres especies de Opuntia (Cactaceae) del desierto Chihuahuense. Cact Suc Mex. 52: 46-52.

Mandujano MC, Montaña C, Rojas AM (2005) Breaking seed dormancy in Opuntia rastrera from the Chihuahuan desert. J Arid Environ. 62: 15-21.

Mandujano MC, Montaña C, Eguiarte LE (1996) Reproductive ecology and inbreeding depression in Opuntia rastrera (Cactaceae) in the Chihuahuan desert: why are sexually derived recruitments so rare?. Am J Bot. 83: 63-70.

Mandujano MC, Montaña C, Franco M, Golubov J, Flores MA (2001) Integration of demographic annual variablity in a clonal desert cactus. Ecology. 82: 344-359.

Mandujano MC, Goluvob J, Reyes J (2002) Lo que usted siempre quiso saber sobre las cactáceas y nunca se atrevió a preguntar. CONABIO. Biodiversitas. 40: 4-7.

Mondragón JC, Bordelon B (2002) Presencia de apomixis en cruzas de nopales mexicanos y su identificación molecular preliminar. Rev Fitotec Mex. 25 (3): 247-252.

Monroy VM, Peña VC, García NJ, Solano CE, Campos H, García VE (2017) Imbibición, viabilidad y vigor de semillas de cuatro especies de Opuntia con grado distinto de domesticación. Agrociencia. 51(1): 27-42.

Muñóz UA, Palomino HG, Terrazas T, Gracía VA, Pimienta BE (2008) Variación anatómica y morfológica en especies y entre poblaciones de Opuntia en la porción sur del Desierto Chihuahuense. Bol Soc Bot Mex. 83: 1-11.

Murashige T, Skoog FA (1962) A revised medium for rapid growth and bioassays with tobacco tissue cultures. Physiol Plant. 15(3): 473-497.

Olvera CY (2001) Estudio ecofisiológico de la germinación, sobrevivencia y crecimiento de Opuntia tomentosa s.d. en la reserva del pedregal de San Ángel. Tesis. Universidad Nacional Autónoma de México. 94p.

Orozco SA, Márquez GJ, Sánchez CME, Gamboa BA, Baskin JM, Baskin CC (2007) Seed anatomy and water uptake in relation to seed dormancy in Opuntia tomentosa (Cactaceae, Opuntioideae). Ann Bot. 99: 581-592.

Palleiro N, Mandujano MC, Golubov J (2006) Aborted fruits of Opuntia microdasys (Cactaceae): insurance against reproductive failure. Am J Bot. 93: 505-511.
Pérez HE, Almira F, Brennan M (2009) Germination timing and dormancy break in seeds of summer farewell (Dalea pinnata, Fabaceae). Ecol Restor. 27 (2): 160-168.

Pinkava DJ (2002) On the evolution of the continental North American Opuntioideae (Cactaceae). Succ PI Res. 6: 59-98.

R Development Core Team (2017) R: A language and environment for statistical computing. $R$ Foundation for Statistical Computing. Vienna, Austria. In: http://www.Rproject.org. Access in: 01 August, 2017.

Reyes-Agüero JA, Aguirre JR, Hernández HM (2005) Systematic notes and a detailed description of Opuntia ficus-indica (L.) Mill. (Cactaceae). Agrociencia. 39 (4): 395408.

Reyes-Agüero JA, Aguirre JR, Valiente-Banuet A (2006) Reproductive biology of Opuntia: A review. J Arid Environ. 64: 549-585.

Sáenz C, Berger H, Corrales GJ, Galletti L, García CV, Higuera I, Mondragón C, Rodríguez FA, Sepúlveda E, Varnero MTE (2006) Utilización agroindustrial del nopal. Boletín de Servicios Agrícolas de la FAO. In Cadmo Rosell. Roma. $113 p$.

Sánchez UA, Suárez CE, Tusent PJ, Labarca SC, Baruch APV, Colmenarez OCB, Peña CBV (2016) Tratamientos pregerminativos de semillas y emergencia de las plántulas de Opuntia streptacantha Lem. Rev Fac Agron. 33: 193215.

Sánchez SJ, Jurado YE, Pando MM, Flores RJ, Muro PG (2010) Estrategias germinativas de las semillas en ambientes áridos. Rev Chap Serie Zonas Áridas. 9 (1): 35-38.

Sánchez SJ, Flores J, Muro PG, Arias MS, Jurado E (2015) Morfometría de semillas en la cactácea amenazada de extinción Astrophytum myriostigma Lemaire. Polibotánica, (39):119-131.

Sánchez VG (1997) Germinación, viabilidad y características distintivas de la semilla de Opuntia joconostle Weber, forma cuaresmero. Cact Suc Mex. 42: 16-21.

Scheinvar L (2009) Diez especies mexicanas productoras de xoconostles: Opuntia spp. y Cylindropuntia imbricata (Cactaceae). In: Universidad Nacional Autónoma de México (ed) 1ra edn. México. 177p.

Schütz W, Milberg P, Lamont BB (2002) Seed dormancy, after-ripening, and light requirements of four annual Asteraceae in south-western Australia. Ann Bot. 90: 707714.

Thompson K, Ceriani RM, Bakker JP, Bekker RM (2003) Are seed dormancy and persistence in soil related? Seed Sci Res. 13:97-100.

Villavicencio GE, Cano PA, Juárez SA (2009) Micropropagación y producción de plantas del bonete 0 birrete de obispo, cactácea ornamental amenazada de extinción del desierto Chihuahuense. INIFAP-CIRNE. Coahuila, México. 42p.

Wallace RS, Dickie SL (2002) Systematic implication of chloroplast DNA sequence variation in subfam. Opuntioideae (Cactaceae). Succulent Plant Res. 6:9-24. 